\title{
Derleme
}

\section{Psikiyatri hemşireliği öğretiminde simülasyon kullanım modelleri}

\author{
Birgül Özkan', Nesibe Günay Molu² \\ 1Yıldırım Beyazıt Ü., Sağlık Bilimleri Fakültesi, Psikiyatri Hemşireliği AD., Ankara \\ ${ }^{2}$ Necmettin Erbakan Ü., Sağlık Bilimleri Fakültesi, Psikiyatri Hemşireliği AD., Konya
}

\begin{abstract}
Öz
Birçok alanda olduğu gibi hemşirelik eğitiminde de kullanılan simülasyon uygulamaları; psikiyatri hemşireliği öğrencilerine, güvenilir ve pozitif öğrenme ortamında, psikiyatrik girişimleri yapabilmeyi, kriz yönetimini, terapötik iletişim becerilerini kullanabilmeyi, eleştirel düşünmeyi, karar vermeyi, interaktif öğrenmeyi, problem çözmeyi, kendini terapötik kullanmayl vb öğrenme fırsatı sağlamaktadır. Öğrencilere bilgi, beceri ve deneyim kazandırmak için, hemşirelik simülasyonlarının oluşturulması esnasında öğrenme teorilerinin rehber alınması simülasyon deneyimlerinin gelişimine destek sağlamaktadır. Literatürde çok farklı teknikler kullanılarak yürütülen ruh sağlığı simülasyonları bulunmaktadır. Ruh sağlığı hemşireliği eğitiminde en yaygın kullanılan simülasyon teknikleri; standardize edilmiş hasta ile simülasyon, aslına uygun (yüksek duyarlılıkta) simülasyon, sanal hastalar (gerçeklikler) ve ses işiterek yapılan simülasyondur. Hemşirelik eğitiminde simülasyon kullanımının hem eğiticiler hem de öğrenciler üzerinde bir çok olumlu etkisi bulunmaktadır. Psikiyatri hemşireliği eğitimde kullanılan simülasyon uygulamaları ülkemizde psikiyatri hemşireliği eğitiminde yaygın olarak kullanılmamakta ve psikiyatri hemşireliği eğitimde kullanılan simülasyon uygulamaları ile ilgili yeterince çalışma bulunmamaktadır. Farklı yöntemler ile yapılan simülasyon tekniklerinin psikiyatri hemşireliği alanına birçok katkısı olacağı düşünülmüş ve bu nedenle simülasyon kullanımı ile ilgili farkındalığı artırmak amacı ile bu derleme yapılmıştır.
\end{abstract}

Anahtar Kelimeler: Psikiyatri hemşireliği, simülasyon, öğrenci eğitimi, öğrenme teorileri

\section{Simulation usage models in psychiatric nursing teaching}

\begin{abstract}
Used in nursing education as well as on many other areas, simulation applications provides psychiatric nursing students making psychiatric inventions, crisis management, use of therapeutic communication skills, critical thinking, making decision, interactive learning, solving problem, using himself/herself in therapeutic manner etc. in a reliable and positive learning environment. Taking learning theories as a guide during formation of nursing simulations to bring knowledge, skills and experience to students supports development of simulation experiences. There are several mental health simulations that employ different techniques.
\end{abstract}

Yazının geliş tarihi: 08.03.2017

Yazının kabul tarihi: 11.08.2017

Sorumlu Yazar: Nesibe Günay Molu, Necmettin Erbakan Üniversitesi, Sağlık Bilimleri Fakültesi, Hemşirelik Bölümü, Psikiyatri Hemşireliği AD. Tel: 033232040 49/2033 E-posta: ngmolu@konya.edu.tr 
In mental health nursing education, the most common use of simulation techniques are; simulation with the standardized patient, literal simulation (high sensitivity), simulation with virtual patient (relatives) and hearing sounds. Using simulation in nursing education has many positive effects on both educators and students. Simulation applications used in psychiatric nursing education are rarely used in psychiatric nursing education in our country and likely studies about simulation applications used in psychiatric nursing education are underrepresented. This review work was carried out to raise the awareness regarding the use of simulation, originating from the point of view that simulation techniques with different methods has a significant influence on the field of psychiatric nursing.

Keywords: Psychiatric nursing, simulation, education of students, learning theories

\section{Giriş}

Günümüzde birçok eğitim alanında
kullanılan simülasyon, son yıllarda
hemşirelik eğitiminde de kullanılmaya
başlamıştır. Simülasyon, bir şeyin benzeri
veya sahtesi anlamında kullanılmakta ve
benzetim olarak ta isimlendirilmektedir.1
Simülasyon, gerçek hayattaki işlevlerin,
ilişkilerin, olayların, ekipmanların,
davranışların ya da bazı bilişsel aktivitelerin
taklit edilmesi olarak tanımlanmakta ve
"gerçek yaşama olan uygunluk" özelliği
bulunmaktadır. Sağllk alanında; klinikte
yaşanması muhtemel bir durumu
olabildiğince gerçeğe yakı bir şekilde
yansıtarak klinikte gerçekten bu durum
yaşandığında bunun daha anlaşılabilir ve
yönetilebilir olmasını sağlayan bir yöntem
olarak simülasyon kullanılmaktadır.

Hemşirelik eğitiminde simülasyon kullanımı, hemşireliğin bilim ve sanat olarak öğrenilmesinde ve öğretilmesinde yenilikçi yaklaşımlar sağlamaktadır. Simülasyon hem eğiticiler hem de öğrenciler için hemşireliğin kavramsallaștırılması ve sunulmasını ileri düzeye taşımaktadır. Simülasyon gerçek hayat deneyimlerini artırmak için kullanılan bir öğretim yöntemi olarak tarif edilmektedir. Bilgi edinme ve beceri geliştirme açısından, lisans düzeyindeki hemşirelik eğitiminde simülasyon kullanımı literatürde yer almaktadır. ${ }^{3}$ Özellikle ruh sağlı̆̆ ve hastalıkları hemşireliği eğitiminde kullanılan simülasyon; hata nedeniyle hastaya zarar verme ya da yarar sağlamama riski olmadan güvenli bir ortamda bilgi ve beceri kazanmak için uygulanan bir yöntem haline gelmiştir. Bunun yanı sıra empati gibi ruh sağlı̆̆ı hemşireliği için beceri geliştirmede önemli olan kavramlar belirlenmekte, uygulama ile teorik bilgi arasında bağlantı sağlanmakta ve bu nedenle belirli eksikliklerin olduğu müfredat programlarında simülasyon tekniklerine dayalı içerik benimsenmektedir.3-7

Önyarglar, damgalama, anksiyete ve korku gibi durumlar bu deneyimlerin gerçek hasta üzerinde kazanılmasına engel olmaktadır. Bununla birlikte; öğrenciler uygulamada hasta sirkülasyonunun fazla olması, personel yetersizliği, klinik uygulama saatlerinin az olması nedeniyle tüm vakalar ile karşslaşamamakta ya da sağlık kurumlarının öğrenci hemşirelerin çalışmalarını kısıtlayan politikaları nedeni ile öğrenmede engeller yaşamaktadırlar. $\mathrm{Bu}$ nedenle hemşirelik eğitiminde simülasyon kullanılması önem kazanmaktadır.3,7,8

Ülkemizde psikiyatri hemşireliği eğitiminde simülasyon yaygın olarak kullanılmamakta ve psikiyatri hemșireliği eğitimde kullanılan simülasyon uygulamaları ile ilgili yeterince çalışma bulunmamaktadır. Farklı yöntemler ile yapılan simülasyon tekniklerinin psikiyatri hemşireliği alanına birçok katkısı olacağı düşünülmektedir. $\mathrm{Bu}$ derleme psikiyatri hemşireliği öğrencilerinin eğitiminde kullanılan simülasyon yöntemlerini gözden geçirmek amacıyla yapılmıştır.

\section{Simülasyon Eğitiminin Etkileri}

Simülasyon psikiyatri hemşireliği öğrencilerine, sakin ve pozitif öğrenme ortamında, hastaya bakım verme esnasında, psikiyatrik girişimleri ve kriz yönetimini öğrenme fırsatı sağlamaktadır. Psikiyatri hemşireliği eğitiminde simülasyon kullanımı öğrencilere, terapötik öğretim becerileri, 
eleştirel düşünme, karar verme, yapılan girişimleri durdurabilme, interaktif öğrenme, problem çözme, kendini terapötik kullanma, kriz yönetimi, iletişim becerileri, öz yeterlilik, özgüven, kültürel yeterlilik ve klinikte düşünme/karar verme yetileri kazandırmaktadır..-7 Yapılan çalışmalarda simülasyon ile çalışan öğrencilerde, klinik ile ilgili algılarının arttığı, kompleks psikiyatri hastası ve çevrenin anlaşılmasının kolaylaştı̆̆l, psikiyatri hemşiresinin rollerini keşfettikleri ve etkili takım çalışmasının bilincine vardıkları belirlenmiştir. ${ }^{9}$ Ruh sağlığı hemşireliği ve psikoloji bölümü öğrencilerinin eğitimlerinde kullanılan simülasyon deneyimlerinin sonucunda ruh sağlığı konularında farkındalıklarının arttığı tespit edilmiştir. ${ }^{10}$ Simülasyon eğitimleri her öğrenciye eşit yaklaşım firsatı ve uygun ortamlarda yetişkin öğrenme ilkelerinin etkin olarak kullanımını sağlamaktadır. ${ }^{11}$

Simülasyon aktiviteleri, insan dahil, hasta simülatörleri/mankenleri, standardize hasta rolünü oynayan insanlar, sanal hasta ve çevrelerin kullanıldığı bilgisayar odaklı modeller ile oluşturulmuş çeşitli mekanizmalar kurularak yapılmaktadır. Klinik bilgi ve becerileri artırma amaçl, katılımcılar pasif olarak gözlemleyebilmekte veya simülasyon egzersizlerine aktif bir şekilde katılabilmektedirler. ${ }^{8}$ Öğrencilere duygu durum değişikliği, düşünce bozuklukları, kişilik bozuklukları gibi durumlarda simüle edilmiş hastanın her türlü ihtiyacını karşılama esnasında, somut, duygusal bir deneyim kazanmalarını sağlamaktadır. Öğrencilere akranları tarafından yargilanmadan değerlendirilme fırsatı sağlamaktadır.12 Öğrencilerin simülasyon esnasındaki belirlenen ihtiyaçlarına göre uygulamalar ve senaryolar tekrar edilebilmekte, öğrenciler tarafından aktif öğrenme ilkeleri ile kavramlar arasında bağlantı kurulması sağlanmaktadır. ${ }^{6}$ Değerlendirmelerde hemşire öğrencilerin kendilerinde var olan negatif tutumlarını belirleyebilmelerini, duygularını, düşüncelerini açıklayabilmelerini, kaygıll, çekingen ve rahatsız edici davranışlarını fark edebilmelerini, kendi kendini motive edebilme ve öz yönetim yapabilmelerini de sağlamaktadır.6, 9
Hastanede, hasta ve öğrenci etkileşimlerinin olduğu alanlar olan psikiyatri klinikleri, gizlilik ve çevre sorunları nedeni ile öğrenciyi değerlendirebilmek ve bilgi becerilerini geliştirebilmek için eğitimciye yeterince gözlem yapma firsatı vermemektedir.10 Psikiyatrik simülasyon akut psikiyatrik hasta bakımında, hastaya verilen bakımın profesyoneller tarafından tartışılmasını, beklentilerin açıklanmasını, her öğrencinin verdiği bakımı gözlemleyebilmeyi, öğrencilerin güçlü ve zayıf yönlerini tespit ederek öğrenciyi güçlendirmeyi sağlamaktadır. ${ }^{2}$ Öğrenme hedeflerine uygun simülasyonlar kullanılarak hedefe daha uygun ulaşılmaktadır. 6

Bununla birlikte simülasyonun avantajlarına rağmen dezavantajları da bulunmakta ve bu nedenle simülasyon eğitimlerinin dikkatli kullanılması gerekmektedir. Simülasyon eğitimleri uygun vaka seçimi, uygun zaman, uygun senaryo ve değerlendirmeleri kapsamalıdır. Standartlaştırılmış hasta veya mankenlerin kullanımı, aynı anda dahil edilebilecek öğrenci sayısı, öğrenciye uygun ekipman yeterliliği, alanın uygunluğu sinırlılıkları artırmaktadır. Dahası, yüksek hassasiyetli mankenlerin kullanımı maliyeti artırmakta, farklı senaryolara uyarlayabilmek, simülatörün cevap vermesi (mankenin, yapılan müdahalelere tepki vermesi) ve beraberindeki ekipmanlar da maliyetin artmasına neden olmaktadır. 8

\section{Hemşirelikte Simülasyon Kullanımı ve Öğrenme Teorileri}

Öğrenme teorileri; öğrencilere bilgi, beceri ve deneyim kazandırmak için, hemşirelik simülasyonlarının oluşturulması esnasında rehberlik ederek simülasyon deneyimlerinin gelişimine destek sağlamaktadır.13,14 Simülasyon uygulaması ve geliştirilmesi sırasında kavramsal çerçeve kullanılması gerekmektedir. ${ }^{13}$

1. Bandura (1965-1995)'nın Sosyal Öğrenme Kuramı klasik ve edimsel koşullanmayı temel alarak insanın sosyal çevrenin etkileri ile öğrenmesinin geliştiğini söylemektedir. Birey uygun davranış geliştirmeyi prova ya da taklit etme ihtiyacı duymadan başkalarını 
gözlemleyerek sağlamaktadır. $\mathrm{Bu}$ öğrenme teorisine göre eğitimlerde simülasyon bir beceri, desen veya rol oynama tekniği için tasarlanmakta, planlanmakta ve uygulanmaktadır. Kavramların öğrenilmesinden ziyade becerilerin öğrenilmesine odaklanan simülasyon uygulamaları katılımcıların tepki ve geri bildirimlerine de firsat verecek şekilde tasarlanmaktadır. ${ }^{13-15}$

2. Kolb tarafından geliştirilen (1984), Deneyimsel Öğrenme Teorisi deneyim yoluyla bilgi yaratma sürecini ele almaktadır. Yani deneyimlerin bilgiye dönüştürülme sürecidir. Kolb’a göre deneyimsel öğrenme a) somut deneyim, b) gözlem ve yansitma c) soyut kavramsallaștırma, d) aktif deneme olmak üzere dört aşamada gerçekleşmektedir. ${ }^{13}$ Deneyimsel öğrenmede "öğrenciler karşılaştıkları durumları fark eder ve düşünür, bu farkındalığa dayanarak bilişsel modeller gelișir ve karşılaștıkları durum hakkında kararlar alır" şeklinde belirtilmektedir. Yansıma ve inceleme bu teorinin temel bileșenleridir. $\mathrm{Bu}$ öğrenme modelinde öğrencilerin aktif katılımı gerekmektedir. Bu teoride bilgi, öğrencilerin olaylara bir anlam yüklediğinde oluştuğunu ileri sürer. $\mathrm{Bu}$ anlam verme; öğrenciler ve eğitmenler arasında oluşan diyalog ve işbirliğini içeren bir dinamik süreçtir. Simülasyon deneyimi öğrenci hemşireler için önem arz etmektedir. ${ }^{14}$

3. Bir diğer teori Schön (1983) tarafından geliştirilen Yansıtıcı Uygulama Teorisi'dir. Eylemin ne olduğunu ya da niçin olduğunu tanımlamaktadır. $\mathrm{Bu}$ teoriye göre yansıtıcı düşünme eylem yapıldıktan sonra geriye dönüp eleștirel düșünme yolu ile ya da eylem esnasında bireyin bir eylemi gerçekleştirirken yaptığı iş hakkında düşünebilmesi yolu ile yapılmaktadır.13-16 Deneyimsel yeterlilik gerektiren kompleks durumlarda uygulayıcılar; gözlemleyerek, yaparak ve yansitarak öğrenmekte ve daha sonra yeniden tekrar yapmaktadır.14 Simülasyon eğitiminde öğrenciler yaptıkları uygulamaları kaydetmekte, durdurup tekrar izleyebilmekte ve uygulamaları tekrar tekrar yapabilmektedirler. Ayrica simülasyondan sonra öğrencilerin rapor yazması simülasyonun etkinliğini artırmaktadır. ${ }^{13}$

4. Knowless (1980-1990) tarafından geliştirilen Yetişkin Öğrenme Kuram'ı ise; davranışçı yaklaşımdaki güçlendirme, genelleme ve aktarım ilkelerine dayanmaktadır. Bu kurama göre yetişkinlerin öğrenmede kullandıkları öz yönelim ve motivasyon kavramları hedef alınarak uygulanmaktadır. Örneğin simülasyon eğitimleri öncesinde eğitimin amaçları, istenilen hedef davranışlar belirlenirse yetişkinler eğitim için motive olacak ve simülasyonun etkinliği artacaktır. Bununla birlikte bu öğrenme kuramının Lewin (1997) değişim teorisi ile birlikte kullanılması daha olumlu sonuçların oluşmasını sağlamaktadır. Simülasyon eğitimlerinden önce öğrencilerin; motivasyonları, düşünme tercihleri veya stilleri ve yaklaşımlarının belirlenmesi simülasyon tarzının belirlenmesi için bilgi sağlayacaktır. Knowles ve Lewin'in teorilerine göre simülasyondan önce öğrenciler hakkında ön değerlendirme yapılması gerekmektedir. ${ }^{13}$

5. Sosyal Yapı Teori'sine göre; bilgi düşündügün değil yaptıklarınla oluşmaktadır. Simülasyonun etkili olmasının öğrencilere verilen görevlere bağlı olduğuna inanılmaktadır. Bununla birlikte öğrencilerden geri bildirim alınmasının önemli olduğuna vurgu yapılmakta ve öğrenciler tarafından yapılan geri bildirimlere göre daha sonraki simülasyon tasarımlarına da yön verilebilmektedir. ${ }^{13}$

6. Bilişsel Stiller Kuram'ına göre; Bütüncül/ayrıștırıcı boyut ve görsel/sözel boyut olarak iki temel boyutta ele alınan bilișsel stiller öğrenme sürecine odaklanmakta ve bilgi işleme sürecinde önemli bir yere sahip olmaktadır. Öğrencilerin çevrelerini nasıl algıladıkları, nasıl etkileşime girdikleri ve nasıl tepkide bulundukları, bilgiyi nasıl işledikleri ve sakladıkları, öğrencilerin beklentileri ve deneyimleri önem kazanmaktadır.13,15 Öğrencilerin sorgulama ve problem çözme becerisine sahip olmaları gerekmektedir. ${ }^{17}$ Simülasyon eğitimlerinde öğrencilerin 
bilișsel stillerine uygun yöntemlerin kullanılması vurgulanmaktadır. ${ }^{13,15}$

gerektiği

7. Yapılandırmacı Öğrenme Kuram'ına göre; bireylere aktivite ve deneyimler ile anlamlar eklendiğinde bilginin inşa edildiğine inanılmaktadır. $\mathrm{Bu}$ kurama göre bireyin kendisi ve sosyal çevre olmak üzere iki şekilde bilgi inşa edilmektedir. Birey bilgiyi araştırma ve yorumlama ile analiz eder, geçmişteki yaşantılar ile bütünleştirir. ${ }^{15}$ Tartışmalara aktif olarak katılmak, konuyu farklı bir perspektifle incelemek araştırmak gerekmektedir. Ayrıca teoride hasta ile işbirliğini kurmak ve güçlendirmek için grup içinde tartışmalara zemin hazırlamak ve öğrenciyi rolünü de belirleyerek grup içine yerleştirmek gerekmektedir. ${ }^{17}$ Simülasyonda aktif öğrenme için ortam sağlanmakta, öğrencide var olan hasta ile ilgili önceki deneyim ve bilgiler ilesimülasyonla kazanılan deneyimler ve bilgiler bir araya getirilip anlamlandırılarak kişisel yapılandırıcı yönelim sağlanmaktadır. Simülasyona katılan ekibin diğer üyeleri ile oluşturulan diyalog ve işbirliği ile de sosyal yapılandırıcı yönelim sağlanmaktadır. ${ }^{15}$

Simülasyon deneyimleri benzer öğrenme teorilerini kullanarak klinik uygulamalarda öğrencilerin; kendi bilgilerini oluşturmalarını, kendi gözlemlerine dayanan fikir ve görüşlerini ifade etmelerini, yapılacak eylemler hakkında karar vermelerini, bu kararları yansıtmalarını ve ardından bu kararları yürütmelerini sağlamaktadır. ${ }^{14}$ Öğrenciler simülasyonun bir parçası olan çözümleme ile deneyimlerini, ne öğrendiğini, bașka neler yapılabileceğini gözden geçirmektedir. Simülasyon öğrencilerin mevcut ve oluşturulan bilgilerine anlam katarak öğrencilerin bu bilgileri kullanmasını sağlamaktadır. ${ }^{15}$

\section{Psikiyatri Hemşireliği Eğitiminde Kullanılan Simülasyon Yöntemleri}

Literatürde ruh sağlı̆̆ı hemșireliği eğitiminde kullanılan çok farklı teknikler kullanılarak yürütülen simülasyonlar yöntemleri bulunmaktadır. Ruh sağlığı hemşireliği eğitiminde en yaygın kullanılan simülasyon teknikleri; standardize edilmiş hasta ile simülasyon, aslına uygun (yüksek duyarlılıkta) simülasyon, sanal hastalar (gerçeklikler) ve ses işiterek yapılan simülasyondur.2,6,18

\section{Standart Hastalar ile Simülasyon}

Standart hastalar; doğru ve tutarlı bir şekilde tıbbi ya da hastalık durumunu canlandırmak üzere eğitilmiş bireylerdir. Bir senaryonun her canlandırılışında aynı performansı göstermek üzere eğitilmektedirler. Simülasyon deneyimlerinde sıklıkla kullanılan bu yöntem, gerçek hayattaki klinik senaryolarını öğrencilere sunarak ve gerçeklik düzeyini artırarak, öğrencilerin güvenli ve tehditkar olmayan bir çevrede karar verme, problem çözme ve iletișim becerilerini geliștirmektedir. Ruh sağlı̆̆ klinik uygulamalarına giden öğrenciler arasında yoğun anksiyete yaşandığ görülmektedir. Standart hasta yöntemi kullanılarak eğitim verilen öğrencilerde ruhsal hasta ile karşılaştıkları zaman anksiyete duygusu daha az yaşanmakta ve özgüvenleri artmaktadır. Ruh sağlığı simülasyonlarından standardit hasta simülasyonu eğitimlerine katılan öğrencilerle yaplan çalışmalarda öğrencilerin; hasta ile görüşme deneyimlerinin, hastaların şikayetlerini değerlendirebilme yetilerinin ve terapötik iletişim becerilerinin geliştiği, güven duygusunun arttığı, anksiyete düzeylerinin azaldığ bildirilmiștir.2,19,20 $\mathrm{Bu}$ yöntemde öğrenciler hem hastayı hem de hemşireyi canlandirabilmekte ve standart hasta ile simülasyon yöntemi genellikle iletişim becerileri eğitiminde kullanılmaktadır. ${ }^{2}$ Simülasyondaki bu teknik sayesinde öğrenciler hastayı da canlandırdıkları için hastaların psikotik belirtilerini deneyimleyebilmekte, hastaların belirtilerini tanımakta, hastaların ne yaşadıklarını ve ne düşündüklerini daha iyi fark edebilmekte ve böylece öğrencilerde empati becerileri de gelişmektedir. ${ }^{20}$

Yüksek Uyumlu İnsan Simülasyonu: High Fidelity Human Simulation (HFHS) 
Yüksek

simülasyonunda etkileşime izin veren, ileri teknoloji ile donatılmış mankenler kullanılır. $\mathrm{Bu}$ mankenler öğrenci uygulamalarında müdahalelere anında cevap veren teknolojik açıdan gelişmiş cihazlardır. ${ }^{3}$ Yüksek uyumlu simülatörlerin kullanımı ile risksiz ortamda öğrenme dahil olmak üzere; interaktif öğrenme, uygulamaya karar verme ve gelişmiş değerlendirme becerisine sahip olma, geribildirim yapma, simülasyonu durdurup yeniden başlatmaya karar verebilme, eleştiri yapma, ruh sağlı̆̆ kavramlarını anlayabilme ve standardize öğrenme yeteneğine sahip olma becerilerini artırmaktadır. ${ }^{21} \quad$ Yüksek uyumlu simülatörlerin kullanıldığı bu teknik öğrencilerin terapötik iletişim becerileri, kritik düşünme ve karar verme düzeylerini geliştirmekte, güvenli ve öğretici bir çevrede anksiyete düzeylerini azaltmakta, takım çalışmasını ve hasta güvenliğini artırmayı sağlamakta, hastalar ile çalışırken bilgi ve becerilerini kullanabilmeyi artırmaktadır, böylece öğrenciler "kendini terapötik kullanmayı etkili bir şekilde kullanabilmektedirler. ${ }^{3,14} \mathrm{Bu}$ teknik hasta ile terapötik ilişki kurmada yardımcı olacak ve ruh sağlığı hemşireliğini bir kariyer seçeneği olarak daha ilgi çekici hale getirecektir. ${ }^{7}$

Kameg ve ark. ${ }^{21}$ yaptıkları çalışmada; yüksek uyumlu simülatörlere uzman kişiler tarafından oluşturulan; akut alkol geri çekilme sendromu yaşayan hasta, partneri tarafından şiddet görerek travma yaşayan hasta, doğum sonu depresyon yaşayan hasta olmak üzere 3 senaryo yükleyerek öğrenci eğitimleri yapmış ve sonunda hemşire öğrencilerin pozitif öğrenme deneyimi kazanarak olumlu geri bildirimlerinin olduğunu belirlemişlerdir. Murray $^{14}$ ilaç ve alkol kötüye kullanım bozukluğu olan hasta senaryosu ile yaptığı çalışmada öğrencilerde suçlama korkusu olmadan, öğrencilerin hataları daha açık kabul ettiklerini ve kaygılarının azaldığını, Garry ve ark. ${ }^{22}$ yaptıkları çalışmada çocuk ve adölösan psikiyatri hemşireliği uygulamasinda da bu simülasyon yönteminin kullanılabileceğini bildirmişlerdir. Maruca ve Diaz ${ }^{23}$ yaptıkları çalışmada 38 hemşirelik öğrencisinin alkol yoksunluğu sendromu vakası yüklenmiș olan simülatörler ile eğitimlerini yapmışlar ve eğitim sonunda olumlu sonuçların alındığını, psikiyatri hemşireliği eğitimlerinde yüksek uyumlu simülatörlerin kullanımının önemini vurgulamışlardır.

Lehr ve Kaplan ${ }^{24} 54$ hemşirelik öğrencisi ile yüksek uyumlu simülasyon yöntemi kullanarak 2 senaryo çalışması yapmışlar ve sonrasında simülasyon deneyiminin etkinliğini belirlemişlerdir. Çalışmaya katılan öğrencilerin tamamının bu uygulamanın olumlu olduğunu ifade ettiklerini ve değerlendirme formunun her alanını pozitif yorumlarla doldurduklarını bildirmişlerdir. Vurgu yapılan sonuçlara bakıldığında; simülasyon eğitiminin; öğrencilerin \%78'i kritik düşünmelerini sağladığını, \% 80'i düşündüklerini ve karar verdiklerini uygulama becerisi sağladığını, \%78'i simüle hasta bakımında aktif rol aldığı zaman akranları tarafından gözlemlenmesinin öğrenmesini sağladığını, \%83'ü simülasyon sonrası yapılan değerlendirme ve tartışmanın çok etkili olduğunu ifade ettiklerini bildirmişlerdir. Buna ilaveten Unswort ve ark. ${ }^{25}$ Alzheimer hastalığı olan hastada gelişen akciğer enfeksiyonu, ilaç kullanımına bağlı psikoz ve alkol intoksikasyonu senaryosu olan simülatörler kullanarak çalışma yapmışlar ve öğrencilerdeki bilgi eksikliklerini ve bu eksiklikleri gidermek için geliştirilmesi gereken stratejileri, etkili bakım yönetimi için sinırlılıkları ve güçlükleri belirlemişlerdir.

\section{Sanal Hastalar (Gerçekler) (Virtual Patient)}

Online sistemle ya da uzaktan öğrenme bağlamında sanal hastalar olarak ideal simülasyon araçları bulunmaktadır. Gerçek yaşamdan vakalar temel alınarak oluşturulan senaryoların bulunduğu bilgisayar tabanlı interaktif bir simülasyon türüdür. ${ }^{6}$ Bilgisayar tabanlı sanal gerçeklik programları; gerçek ortamları taklit eden ve sanal obje ya da ortam sunan yüksek teknolojiyi kullanmaktadır.,3 Sanal gerçeklik programları öğrencilerde iletişim becerilerini geliştirmeyi ve sağlığ değerlendirme yetisi kazandırmayı hedeflemektedir. Hızlı düşünme ve karar verebilme becerisi ile öyküler 
temellendirilir. $\mathrm{Bu}$ yöntemde dallanma ve doğrusal olmak üzere iki farklı yapıda model bulunmaktadır. Doğrusal yapıda ise seçilebilecek tek bir model vardır. Dallanma yapısında ise; vakaların birçok karar verme yolunu içerdiği ve alınan kararlara göre senaryoların değişiklik gösterdiği belirtilmektedir. ${ }^{3}$ Öğrencilerden vaka esnasında kendilerine uygun olan seçeneği seçmeleri istenerek her seçenek sonunda farklı bir şeklide vakanın ilerlemesi sağlanmakta ve alınan kararların hasta ve klinik çalışanlarını nasıl etkilediği de fark edilmektedir. ${ }^{6}$ Dallanma modeli özellikle kritik karar verme becerilerinin gelişimi için kaçınılmaz bir firsat olarak bildirilmiștir. ${ }^{6}$ Öğrencilere rehber olması için adım adım geri bildirim yapılarak senaryo sonunda alınan farklı kararlar ile sonuçların nasıl değişebileceği tartışılarak gösterilmektedir. $\mathrm{Bu}$ simülasyon uygulamasında, öğrenciler verdikleri kararların hasta üzerindeki farklı etkilerini de değerlendirmekte ve eleştirel düşünme becerisi, deneyim, karar verme, terapötik iletişim teknikleri ve empati yapabilme becerileri kazanmaktadırlar. ${ }^{3}$ Bütün bunların yanında bilgi, beceri ve yeterli donanıma sahip olmayan öğrencilerin gerçek hasta üzerinde değil, simülatörler üzerinde çalışması da sayılabilecek yararları arasında bulunmaktadır. ${ }^{6}$

Genel olarak bakıldığında bu öğretme ve öğrenme aracının merkezinde; öğrenme ihtiyaçlarına ve öğretim hedeflerine uygun tasarlanmış simülasyon senaryoları yer almakta ve öğrencilerin gelişimine katkı sağlamaktadır. Sanal hasta simülatörü kullanımı kompleks yapısından ve çok yüksek olmasa da maliyetinden dolayı yaygın olarak kullanılmamaktadır. Ancak ögrretim araçlarında kullanılan yöntemlerin ve teknolojinin gelişmesi ile birlikte bu yönteminde kullanımının giderek artması beklenmektedir. ${ }^{6}$

\section{Sesli İşitme (Voice Hearing)}

Sesli işitme simülasyonu; sesler duyan hastanın yaşadığı deneyimleri büyük oranda anlamayı sağlamak, farkındalığ artırmak ve tutum geliştirmek için ruh sağlığı hemşireliği eğitiminde kullanılan öğretim metadolojisidir. Önyargl ve damgalamanın olumsuz etkilerini kabul ederek, simülasyonda ses işitme yönteminin gelişimi ile iyileşme ve hassas bakım sağlanmaktadır. ${ }^{26}$ Hastaların duyduğu sesler canlandırıldığı için öğrenci hemşirelerde sesler işiten hastalar ile ilgili olarak seslerin hastalar üzerindeki etkilerini ve hastaların duygularını anlama konusunda empati yeteneği gelişmektedir. ${ }^{27}$ Yapılan çalışmada kronik ruhsal hastalığı olan hastaya bakım verme eğitimi alan öğrenci hemşirelere işitsel halüsinasyonları olan oyuncuların sesleri dinletilmiş, öğrenciler sesleri dinlerken; gerçek yaşamdaki gibi hastalar ile etkileşime girmeleri istenmiştir. $\mathrm{Bu}$ yöntemin kullanılmasında aktif sesler işiten, düşünce bozukluğu olan hastaların işaret ve belirtilerinin belirlenebilmesi amaçlanmaktadır. Bunun yanında hastalarda anksiyeteyi azaltmak ve güven inşa etmek için hastalarla nasıl iletişime geçileceğinin, şizofreni tedavisi sonrasında hastayı topluma yeniden kazandırmak için nasıl desteklemek gerektiğinin ve kronik hastalıkla mücadele için birey ve ailenin desteklenmesinin öğrencilere öğretilmesi hedeflenmektedir. ${ }^{26}$ Sonuçta simülasyon eğitimi alan öğrencilerin hastalara karşı negatif tutumlarının daha az olduğunu, korkularının azaldığını ve ruhsal bozukluğu olan hasta ile daha fazla etkileşime girme davranışı gösterdiklerini bildirmişlerdir. ${ }^{26}$

\section{Simülasyon Uygulamalarında Çözümleme}

Genel olarak bakıldığında psikiyatri hemşireliği öğrencilerinin eğitiminde kullanılan simülasyon uygulamalarının son aşaması olan geri bildirim yapmanın önemi vurgulanmakta, içgörü kazanma ve özgüvenin arttığına ilişkin tema elde edilmektedir. Geribildirimler esnasında; akranlarının ve profesyonellerin yapılandırılmış oturumlarda yaptıkları gözlemlere ait yorumlar, olumlu sonuçların alınmasını sağlamaktadır. Bununla birlikte öğrenciler tarafından; yapılan davranışların ve eylemlerin yararlı olup olmadığına ilișkin yorumların direkt duyulmasının çok yararlı olduğu ifade edilmektedir. Öğrencilerin bilgi ve becerilerini artırmak için; benzer veya farklı klinik deneyimleri içeren simülasyonlarda; tartışma alanlarının oluşturulması, videoların tekrar izlenmesi, geri bildirimlerin yapılması, akranların ve 
eğitimcilerin değerlendirmeleri ile iç görülerinin geliştiği ifade edilmiştir. Öğrencilerin bu çalışmalar ile eksik yönlerini tamamlama firsatlarının oluşması, bilgi ve becerilerinin artması kendilerine olan güveninde artmasını sağlamaktadır. ${ }^{28}$ Sonuç olarak literatürde de bildirildiği gibi ruhsal bozukluğu olan hasta ile çalışacak öğrencilerin eğitiminde öğrenme teorilerinin de desteklediği üzere, uygun simülasyon yöntemlerinin kullanılması, özellikle klinik deneyim yaşamadan önce gelişecek olan birçok olumsuz etkiyi azaltarak hem öğrenciye hem de eğiticiye olumlu katkıları olacaktır.

\section{Kaynaklar}

1. Alinier G. A typology of educationally focosed medical simülation tools. Medical Teacher 2007;29:8:243-250.

2. Şendir M. Kadın sağlığı hemşireliği eğitiminde simulasyon kullanımı. F.N. Hem. Derg 2013;(21)3:205-212.

3. Brown A.M. Simulation in under graduate mental health nursing education: A literatüre review. Clinical Simulation in Nursing 2015;11(10):445-449.

4. Kameg K., Mithell A.M., Clochesy J., Howard V.M., Suresky J. Communication and human patient simulation in psychiatric nursing. Issues in Mental Health Nursing 2009;30:503-508.

5. Crider M.C., Niesh S.G. Integrating a Professional apprentice ship model with psychiatric clinical simulation. Journal of Psychosocial Nursing and Mental Health Services 2009;49(5):42-49.

6. Guise V., Chambers M., Valimaki M. What can virtual patient simulation offer mental health nursing education?. Journal of Psychiatric and Mental Health Nursing 2012;19:410-418.

7. Szpak J.L., Kameg K.M. Simulation decreases nursing student anxiety prior to communication with mentally ill patients. Clinical Simulation in Nursing 2013;9(1):13-19.

8. Brown J.F. Applications of simulation technology in psychiatric mental health nursing education. Journal of Psychiatric and Mental Health Nursing 2008;15:638644.
9. Hermanns M., Lilly M.L., Crawley B. Using clinical simulation to enhance psychiatric nursing training of baccalaureate students. Clinical Simulation in Nursing 2011;7:41-46.

10. Oudshoorn A., Sinclair B. Using unfolding simulations to teach mental health concepts in undergraduate nursing education. Clinical Simulation in Nursing 2015;11(9):396-401.

11. Şendir M., Doğan P. Hemşirelik eğitiminde simülasyonun kullanımı: sistematik inceleme. F.N. Hem. Derg 2015;23(1):49-56.

12. Ellis D.M., Brou R., King R., Tusa P. Psychiatric simulation on a budget. Clinical Simulation in Nursing 2015;11(11):469-471.

13. Kaakinen J., Arwood E. Systematic review of nursing simulation literatüre for use of learning theory. International Journal of Nursing Education Scholarship 2009;6(1):1-20.

14. Murray B.A. The use of high-fidelity simulation in psychiatric and mental health nursing clinical education. International Journal of Health Sciences Education, 2014;2(1):1-12.

15. Hemming T.F. Simulation methodology in nursing education and adult learning theory. Adult Learning 2012;23(3):129137.

16. Köksal N., Demirel Ö. Yansıtıcı düşünmenin öğretmen adaylarının öğretmenlik uygulamalarına katkıları. $H$. Ü. Eğitim Fakültesi Dergisi 2008;34:189203.

17. Aliakbari F., Parvin N., Heidari M., Haghani F. Learning theories application in nursing education. J Edu Health Promot 2015;4(2):3-11.

18. Guinness T.M. Simülation in psychiatric nursing education. Journal of Psychosocial Nursing 2011;49(5):9-10.

19. Davis S., Josephsen J., Macy R. Implementation of mental health simulations: Challenges and lessons learned. Clinical Simulation in Nursing 2013;9(5):157-162.

20. Choi Y.J. Standardized patients for kore an psychiatric nursing student simulations. Clinical Simulation in Nursing 2013;9(9):385-392. 
21. Kameg K.M., Englert N.C., Howard V.M., Perozzi K.J. Fusion of psychiatric and medical high fidelity patient simulation scenarios: effect on nursing student knowledge, retention of knowledge, andperception. Issues in Mental Health Nursing 2013;34:892-900.

22. Garry D., Cashin A., Fowler C. Coming ready or not high fidelity human patient simulation in child and adolescent psychiatric nursing education: Diffusion of Innovation. Nurse Education Today 2011;31:655-659.

23. Maruca A.T., Diaz D.A. Does simulation enhance undergraduate psychiatric nursing education? A formative assessment. Advances in Dual Diagnosis 2013;6(1):14-23.

24. Lehr S.T., Kaplan B.A. Mental health simulation experience for baccalaureate student nurses. Clinical Simulation in Nursing 2013;9(10):425-431.

25. Unswort J., Mckeever M., Kelleher M. Recognition of physical deterioration in patients with mental health problems: the role of simulation in knowledge and skill development. Journal of Psychiatric and Mental Health Nursing 2012;19:536545.

26. Sideras S., McKenzie G., Noone J., Dieckmann N., Allen T.L. Impact of a simulation on nursing students' attitudes toward schizophrenia. Clinical Simulation in Nursing 2015;11(2):134-141.

27. Orr F., Kellehear K., Armari E., Pearson A., Holmes D. The distress of voicehearing: The use of simulation for awareness, understanding and communication skill development in undergraduate nursing education. Nurse Education in Practice 2013;13:529-535.

28. Schwindt $R$, Nelis A. Integrating simulationinto a Reflection-Centered Graduate Psychiatric/Mental Health Nursing Curriculum. Nursing Education Perspectives 2015;36(5):326-329. 